\title{
Sustainability of harvest of culpeo foxes in Patagonia
}

\author{
Andres J. Novaro
}

Wildlife hunting, for meat and skins, is an important component of the rural economy in Argentinian Patagonia. Every year thousands of fur-bearing mammals are killed and the impact of this on their populations is unknown. This paper reports on the results of a preliminary investigation into the sustainability of the harvest of culpeo foxes Dusicyon culpaeus in a 1000-sq- $\mathrm{km}$ area of Neuquen Province. Monitoring of fox densities and harvest rates over 5 years on six ranches revealed that, despite intense hunting, the numbers of foxes remained little changed. On the other hand, life-table analysis suggested that the levels of hunting pressure on four ranches were too high to allow fox populations to persist unless they were boosted by immigration. The findings have applications for wildlife managers in establishing sustainable harvest rates and optimal spatial distribution of those rates.

Hunting for fur-bearing mammals is widespread throughout Argentinian Patagonia. Every winter thousands of culpeo foxes Dusicyon culpaeus and Patagonian grey foxes D. griseus, hog-nosed skunks Conepatus chinga and C. humboldtii, and Geoffroy's and Pampas cats, Felis geoffroyi and F. colocolo, are captured with leg-hold traps, shot or hunted with dogs.

Culpeo fox hunting, in particular, is directed towards reducing sheep predation (Bellati and von Thungen, 1990) and is also an important source of income for rural people. On sheep farms in southern Neuquen Province, north-west Patagonia, many ranch workers each hunt between 10 and 25 foxes a year (Novaro and Funes, unpubl. data). For these people, with salaries of \$US120-300 a month, and culpeo fox skins worth an average of \$US15 each, culpeo fox hunting alone represents 4-26 per cent of their annual income. In addition, these people also hunt introduced European hares Lepus capensis for cash, and guanacos Lama guanicoe, rheas Pterocnemia pennata, armadillos Chaetophractus villosus and Zaedyus pichiy, and introduced red deer Cerous elaphus for meat. Thus, wildlife hunting is an important component of rural economies in Patagonia, although its relative importance has not been well studied and government agencies and the general public consider sheep and cattle ranching to be the only significant economic activities in the region.

Between 1975 and 1985, an average of 460,000 skins of 'grey' fox (a description that includes the Patagonian grey fox and the Pampas fox $D$. gymnocercus) were exported from Argentina (Garcia Fernandez, 1991). These exports reached a peak in 1979, when over 1.2 million skins of those two species were exported. Exports have declined since 1979. The export of culpeo fox skins followed a similar trend, but with smaller numbers (Figure 1). It is not clear if these declines in legal exports were the result of decreasing population sizes, increasing domestic use of fox furs (which is significant in the case of the culpeo), or increases in illegal exports (Garcia Fernandez, 1991; Novaro, 1993).

On a regional scale, the numbers of foxes hunted are equally impressive and variable from year to year, although data available are much more limited. In southern Rio Negro Province, northern Patagonia, 791-21,000 foxes (grey and culpeo) were hunted during the six years from 1988 to 1993 (Figure 2) (Subsecretaria de Fauna, 1988, 1989, 1990, 


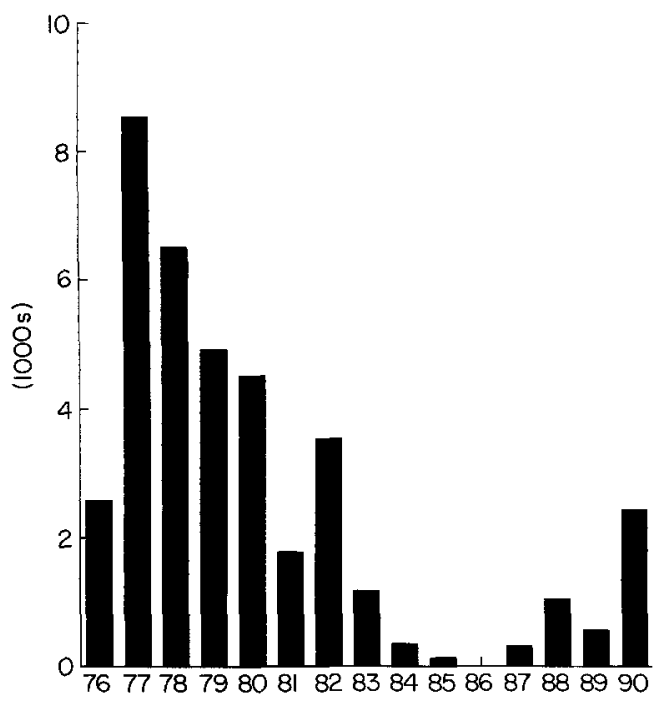

Figure 1. Exports of culpeo foxes Dusicyon culpaeus from Argentina between 1976 and 1990) from Garcia Fernandez, 1991).

1991, and M. Alcalde, pers. comm.).

The impact of this harvest on populations of fur-bearers as well as on all other species hunted is unknown. In 1989 I initiated a study of population trends and the impact of hunting on culpeo and grey foxes in southern Neuquen Province $\left(40^{\circ} \mathrm{S}\right.$ and $\left.71^{\circ} \mathrm{W}\right)$. The purpose of this paper is to report the results of a preliminary evaluation of the sustainability of the harvest of culpeo foxes in this intensively hunted area.

\section{Methods}

An analysis of the dynamics of a harvested population of culpeo foxes was conducted using data on age structure and fecundity from Crespo and De Carlo (1963). These authors worked in the same study area 30 years earlier, collecting carcasses from local hunters. I considered that it was appropriate to use their data because hunting methods, human populations and land-use systems had not changed in the area in the last 30 years. Thus, it was expected that the human impact on fox populations had changed little. Reanalysing their data, I built a life table

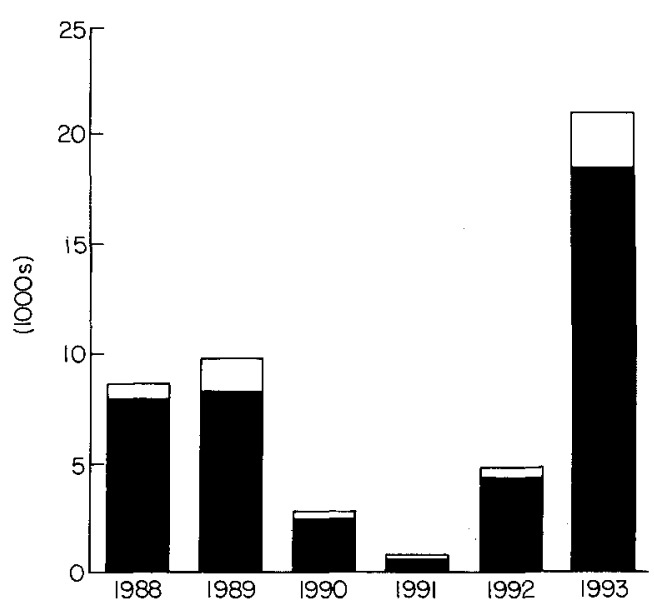

Figure 2. Harvest of Patagonian grey fox Dusicyon culpaeus and culpeo fox D. culpaeus in Rio Negro province between 1988 and 1993 (from Subsecretaria de Fauna, 1988, 1989, 1990, 1991, and M. Alcalde, pers. comm.) $\square$, culpeo fox; $\square$, Patagonian grey fox

(Caughley, 1977) and ran simulations with the computer programme RAMAS/age (Anon., 1990; Novaro, 1991). The trend in culpeo abundance was simulated in 30 replicates run for 50 years.

Between 1989 and 1993 I monitored culpeo and grey fox densities using the scent-station method (Roughton and Sweeny, 1982) on six ranches (Catan Lil, Los Remolinos, La Papay, Cerro de los Pinos, Collun-Co and $\mathrm{La}$ Rinconada) with a total area of approximately $1000 \mathrm{sq} \mathrm{km}$. Most hunting occurred on the first four ranches and there was little or no hunting on the latter two. I estimated harvest rates and some population parameters through the collection of fox carcasses from local hunters (mainly ranch workers). Preliminary estimates of culpeo densities were obtained by combining scent-station with capture data (Novaro, 1991) and from live captures and an on-going radio-telemetry study (Novaro et al., 1993). These estimates of fox density were compared with harvest rates to evaluate the proportion of the population removed annually. 


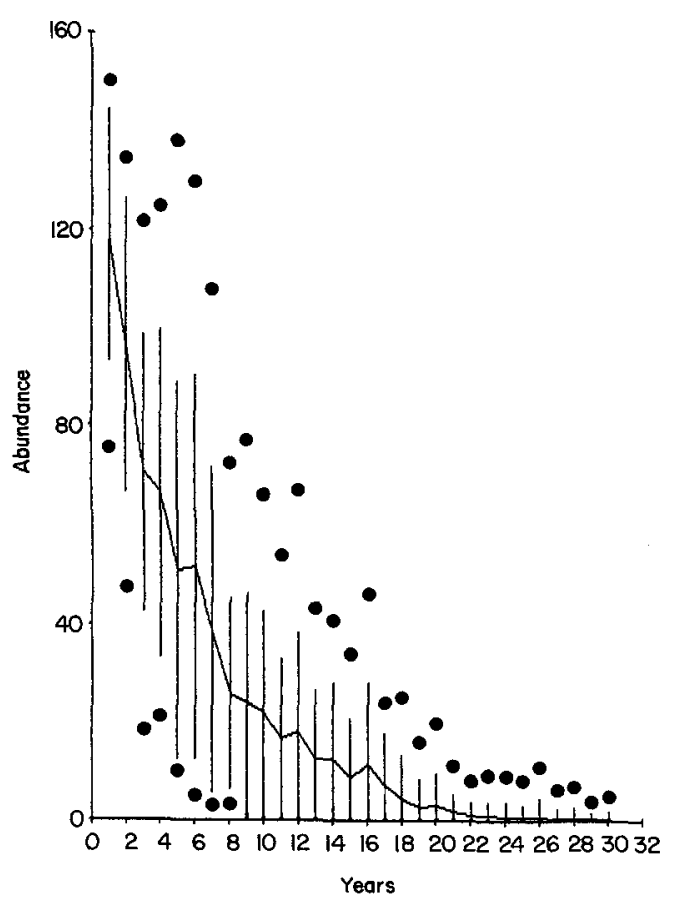

Figure 3. Simulation of culpeo abundance over time with population characteristics derived from Crespo and De Carlo (1963).

\section{Results and discussion}

The estimated age structure of the harvested culpeo population in 1963 was 105, 55, 6 and 1 foxes in 0, 1, 2 and 3-year-old age classes, respectively. The fecundity rate was 1.06 (pups/adult-year), and the survival rates for age classes 0,1 and 2 were $0.52,0.12$ and 0.17 , respectively. The preliminary simulation based on these data showed that culpeo populations could not maintain their numbers and eventually would collapse under the harvest levels at the time (Figure 3 ).

Because culpeo foxes are still abundant in the area, I wondered if harvest rates could have declined during the last three decades since the population age structure data were collected. This was probably not the case, because fur prices increased during the mid1970s (Ojeda and Mares, 1982), producing a higher demand for fox furs, and remained high in the region until the late 1980s (Novaro more than twice and Funes, unpubl. data).

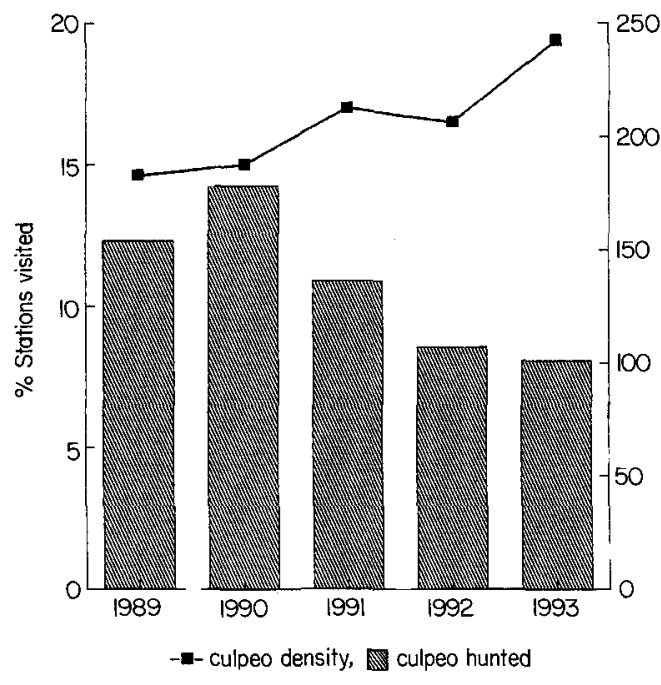

Figure 4. Population trend of culpeo foxes (in proportion of scent stations visited) and minimum number of foxes hunted in the study area in southern Neuquen between 1989 and 1993 (from Novaro and Funes, unpublished data).

Furthermore the sex ratio in the culpeo population has changed during the last 30 years in the direction expected from the response to increased hunting pressure. Crespo and De Carlo (1963) estimated a sex ratio significantly biased towards males ( 0.69 females to 1 male, $n=254$ ), whereas the preliminary data from the same area for the present study showed that the sex ratio now is not significantly different from a 1:1 ratio (0.92 females to 1 male, $n=102$; Novaro, 1991). A change in sex ratio from one biased towards males to a balanced one or biased towards females has been observed in other canids subject to intense hunting pressures, for example coyote Canis latrans (Knowlton, 1972; Berg and Chesness, 1978), and is interpreted as a mechanism that allows populations to withstand high mortality rates temporarily.

The population trend of culpeos in the area shows that in spite of intense hunting their numbers remain little changed and have increased slightly (Figure 4). I was not always able to determine the total number of foxes hunted because of logistical problems, so only the most reliable figures were considered. The minimum number of foxes known to have 
Figure 5. Simulation of culpeo abundance over time with population characteristics derived from Crespo and De Carlo (1963) but with 28 zeroyear-olds immigrating each year.

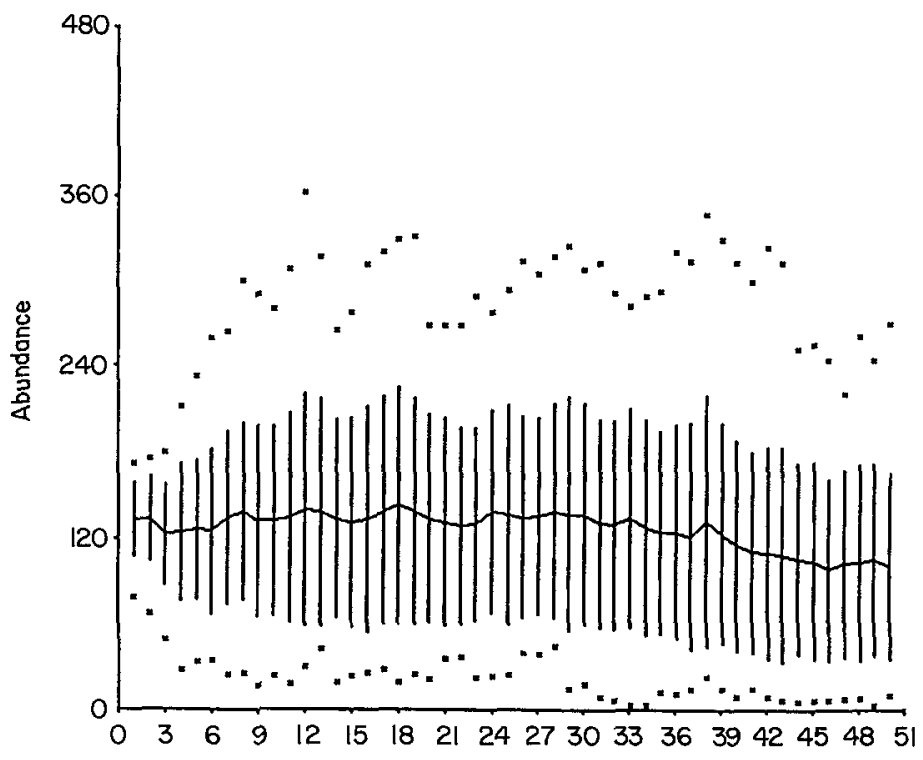

been killed in the study area each year varied between 101 and 178 (Figure 4).

The number of foxes removed annually from each ranch during the study period ranged from 13 to 80 . The average numbers killed each year at the four intensively hunted ranches were estimated at $15,48,55$ and 62 for Catan Lil, Cerro de los Pinos, Los Remolinos and La Papay, respectively. The sizes of these ranches were $180-270 \mathrm{sq} \mathrm{km}$, and annual harvest rates were $0.08,0.27,0.24$ and 0.23 foxes / sq km, respectively.

Preliminary estimates of culpeo densities were 0.11 foxes/sq $\mathrm{km}$ for the lowest density ranch, Catan Lil, and 0.51 foxes/ sq $\mathrm{km}$ for the other ranches. Thus, the proportion of culpeos removed each year in each ranch were 45 per cent at La Papay, 46 per cent at Los Remolinos, 53 per cent at Cerro de los Pinos and 73 per cent at Catan Lil. These extremely high harvest rates agree with the results of the simulations that suggest the culpeo populations could not persist in these intensely hunted areas.

I then performed a second set of simulations of culpeo population dynamics, but introduced an immigration component to the model. As one or more juvenile (zero age class) culpeos are incorporated into the popu- lation of the previous simulation, the population still collapses until 28 zero-year-olds immigrate (Figure 5). In this case the population maintains a steady level for at least the 50 years of which the simulation was performed.

These results indicate that the persistence of culpeos in the study area may be the result of recruitment to the harvested populations by immigration. This conclusion is similar to those obtained for harvested coyotes (Knowlton, 1972; Pyrah, 1984), the Canada lynx Lynx canadensis (Slough and Ward, 1990), and for harvested and unharvested populations of bobcats Felis rufus in Idaho (Knick, 1990). The last author reported that hunting reduced the number of breeding adults in the harvested population to a point where it was too low to produce enough recruits to maintain this population. The conservation of bobcats in Idaho was dependent on the preservation of refugia that were large enough to maintain a constant flow of recruits to the surrounding harvested areas (Knick, 1990). In Patagonia the size and location of these refugia is unknown, but unhunted ranches like Collun-Co and La Rinconada, as well as areas where there are no ranching activities and where the hunting pressure is probably low or 
non-existent, could operate as refugia for the culpeo population.

A more in-depth study is currently being conducted to evaluate the impact of hunting on culpeos using radio telemetry, tagging, return rate of tags and collars from hunters, and computer simulation methods. The goal of this study is to evaluate if the culpeo population dynamic responds to this type of sinksource system (Pulliam and Danielson, 1991) created by hunting, to recommend harvest rates, and to estimate the size of refugia needed to maintain a sustainable harvest. Ultimately, I believe that many hunted species may be able to tolerate high levels of exploitation as a result of a heterogeneous spatial distribution of the hunting pressure. Detecting this type of hunting pattern and population response may allow wildlife managers to reduce the probability of overexploitation by establishing sustainable harvest rates and also optimum spatial distributions of those rates.

\section{Acknowledgments}

This research was conducted with funds provided by the Tropical Conservation and Development Program at the University of Florida, the Wildlife Conservation Society, the Lincoln Park Zoo Scott Neotropic Fund, the Camara Argentina de Peleteria, the American Society of Mammalogists, Sigma $X_{i}$, Patagonia Inc. and FUCEMA while the author was supported by fellowships from the Fulbright Commission and the University of Buenos Aires. Assistance in the field was provided by M. C. Funes, O. Monsalvo, C. Rambeaud, and R. S. Walker, and logistic support by the Centro de Ecologia Aplicada of Neuquen Province. I thank R. Bodmer, S. Humphrey, K. Redford and M. Sunquist for offering helpful comments on the manuscript, and J. Crespo for allowing me to use his data.

\section{References}

Anon. 1990. RAMAS/age. Modelling fluctuations in age-structured populations. Applied Biomathematics. Setauket, New York.

Bellati, J. and von Thungen, J. 1990. Lamb predation in Patagonian ranches. In Proc. 14th Vertebr. Pest Conf. (eds L. R. Davis and R. E. Marsh), pp. 263-268. University of California, Davis.

Berg, W.E. and Chesness, R.A. 1978. Ecology of coyotes in northern Minnesota. In Coyotes: Biology,
Behavior, and Management (ed. M. Bekoff), pp. 229-247. Academic Press, New York.

Caughley, G. 1977. Analysis of Vertebrate Populations. John. Wiley and Sons, Chichester.

Crespo, J.A. and De Carlo, J. 1963. Estudio ecologico de una poblacion de zorros colorados. Revista Museo Argentino de Ciencias Naturales 'B. rivadavia', Ecologia, 1 (1), 1-55.

Garcia Fernandez, J.J. 1991. Administrando para conservar: el caso de los zorros autoctonos de la Argentina. Actas de la III Reunion Patagonica de Manejo de Poblaciones de Zorros, J. de los Andes.

Knick, S.T. 1990. Ecology of bobcats relative to exploitation and a prey decline in southeastern Idaho. Wildlife Monographs, 108, 1-42.

Knowlton, F.F. 1972. Preliminary interpretation of coyote population mechanics with some management implications. J. Wildl. Manage. 36, 369-382.

Novaro, A.J. 1991. Feeding ecology and abundance of a harvested population of culpeo fox (Dusicyon culpaeus) in Patagonia. MS thesis, University of Florida, Gainesville.

Novaro, A.J. 1993. Culpeo foxes in Patagonia. Canid News, 1, 15-17.

Novaro, A.J., Monsalvo, O., Funes M.C., Rambeaud, C. and Walker, S. 1993. Area de accion y densidad del zorro culpeo en un area de estepa del sur del Neuquen. VIII Jornadas Argentinas de Mastozoologia, Bariloche, Argentina.

Ojeda, R.A. and Mares. 1982. Conservation of South American mammals: Argentina as a paradigm. In Mammalian Biology in South America (eds M. A. Mares and H. H. Genoways), pp. 505-521. Pymatunung Symp. Ecol., vol. 6, University of Pittsburgh, Pennysylvania.

Pulliam, H.R. and Danielson, B.J. 1991. Sources, sinks, and habitat selection: a landscape perspective on population dynamics. American Naturalist, 137 (suppl.), 50-66.

Pyrah, D. 1984. Social distribution and population estimates of coyotes in north-central Montana. J. Wildl. Manage. 48, 679-690.

Roughton, R.D. and Sweeny, M.W. 1982. Refinements in scent-station methodology for assessing trends in carnivore populations. J. Wildl. Manage. 46, 217-229.

Slough, B.G. and Ward, R.M.P. 1990. Lynx Harvest Study: 1988/1989 Progress Report. Small Game Section, Yukon Department of Renewable Resources.

Subsecretaria de Fauna. 1988, 1989, 1990, 1991. Sistema Provincial de Acopio de Pieles Finas. Reports to Ministerio de Recursos Naturales, Provincia de Rio Negro, Viedma.

Andres J. Novaro, 118 Newins Ziegler Hall, University of Florida, Gainesville, FL 32611, USA. 